Annals of Warsaw University of Life Sciences - SGGW

Land Reclamation No 40, 2008: 125-130

(Ann. Warsaw Univ. of Life Sci. - SGGW, Land Reclam. 40, 2008)

\title{
Invertebrate and fish environmental preferences as the key factor for lowland riverbed biodiversity
}

\author{
PAWEŁ OGLECKI
}

Warsaw University of Life Sciences, Department of Environmental Improvement

\begin{abstract}
Invertebrate and fish environmental preferences as the key factor for lowland riverbed biodiversity. Detailed biological surveys were carried out on four small and medium lowland rivers (regulated and close-to-nature ones). The typical, repeatable types of microhabitats of peculiar parameters were singled out and the relationships between the microhabitat types and animal taxa were studied. The paper presents the results of such analyses and points out the fact that some microhabitats (irrespective of the fact of river regulation or not) are especially important for the riverbed biodiversity and ecological stability.
\end{abstract}

Key words: invertebrates, fish, lowland rivers, microhabitats, biodiversity.

\section{INTRODUCTION}

One of the most important questions in river surveys is the connection between different abiotic (bottom substrate, water velocity etc.) and biotic factors (plants, invertebrates, fish and a few other vertebrates) - especially in the riverbed zone. Such connections have been presented in different papers (Rabeni and Minshall 1977, Cummings et al. 1966, Berkman et al. 1986, Tolkamp 1980, Beisel et al. 2000), but in reference to elements (factors) of the environment, not to microhabitats as the repeatable environmental structure. It is commonly known that various taxa are of different importance for river eco- systems activity and stability. It depends on their position in the food web and specified ecological group (Lampert and Sommer 1993). The strict impact of every species or even higher taxon on the community or eco-system is usually very hard or impossible to determine, but describing the environmental preferences of basic taxonomical groups seems to be the first step - just to know which microhabitat types (and riverbed structures) are of highest importance for specific invertebrates and fish. It is especially important in the light of biodiversity maintaining and restoration activity (for example according to Water Framework Directive principles).

\section{STUDY AREA AND METHODS}

The studies were carried out on four Polish lowland rivers: middle Wkra in central Poland (medium river according to WFD, 90 kilometres of surveyed reaches), Jeziorka in central Poland (small river, 70 kilometres - all the river course), upper Słupia in northern Poland (medium river, 20 kilometres) and lower Skotawa in northern Poland (small river, 8 kilometres) - Fig. 1. Totally 188 kilometres were surveyed. Among them 65 kilometres may be classified as close-to-nature and 133 as regulated, 


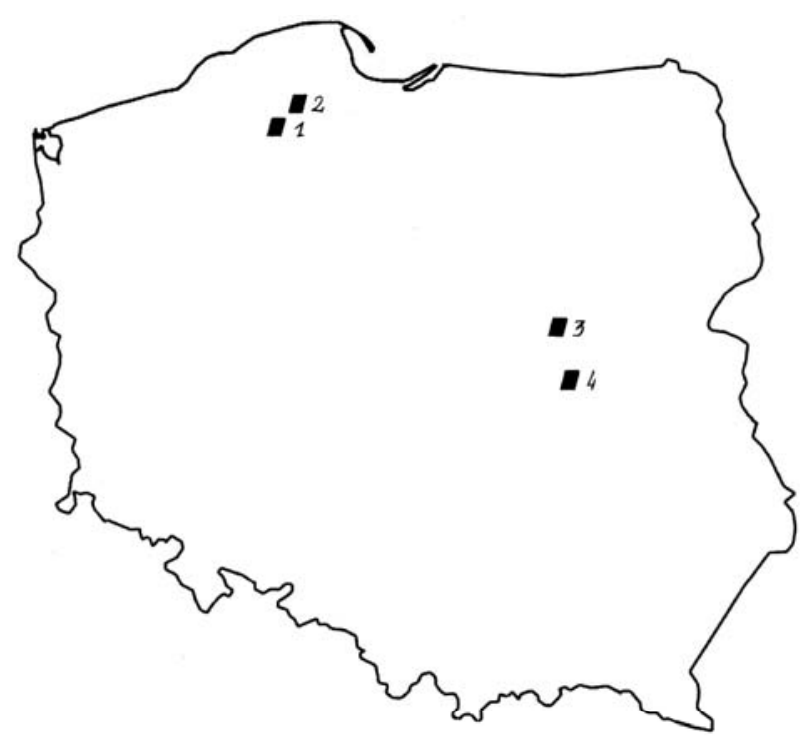

FIGURE 1. The distribution of surveyed river reaches: 1 - Słupia; 2 - Skotawa; 3 - Wkra; 4 - Jeziorka

although in two cases (middle Jeziorka, Wkra) the regulations were performed in an "environmental friendly" way. The general look of such reaches is similar to "natural" one (quotation mark because of the fact that according to some opinions strictly natural rivers do not exist). Sixteen repeatable microhabitats of specific hydrological parameters were singled out - 10 (termed "M") were typical for close-to-nature reaches and often for the regulated ones as well, 6 (termed "R") - only for regulated ones ("artificial"). Although not all those microhabitats were noticed on every river course, in most cases the majority of them might be singled out. During 4 years, in every season (Spring, Summer, Fall-Winter), samples had been collected in all microhabitats (regularly on Wkra and Jeziorka, more occasionally on another 2 rivers; sample coverage $-1-4$ $\mathrm{m}^{2}$ ) - more than 1100 samples in total, not less than 50 samples in each microhabitat.
The samples were collected by means of a triangular dip net, plankton tow, mosquito dipper and Ekman grab. The invertebrates were classified immediately in the field or in the laboratory with professional guidebooks and sometimes with the help of the specialists.

The fish were caught only in Wkra and Jeziorka, in singular points of each site by use of IUP-12 and DEKA-Lord aggregates (with the help of professional ichthyologists) and released after species determination. No other measurements were made since the death rate may be estimated as minimal.

The following types of riverbed microhabitats were singled out on the grounds of collected hydrometrical and hydrological data:

- M-type - typical for close-to-nature reaches, but present also on regulated ones (especially those treated in an "environmental friendly" way): 
- M-1: flat, sandy bottom; water velocity not differentiated,

- M-2: flat, sandy bottom; water velocity differentiated,

- M-3: flat, mixed (sandy and muddy) bottom; water velocity not differentiated,

- M-4: flat, mixed (sandy and muddy) bottom; water velocity differentiated,

- M-5: muddy bottom; stagnant water on outer river bend,

- M-6: muddy bottom; flat bank (water-hole),

- M-7: deep pool on the inner side of the bend,

- M-8: coarse-grained riffle,

- M-9: fallen tree or pile of branches, also the sections upstream and downstream,

- M-10: small tributary or drainage ditch mouth

- R-type - typical for regulated reaches:

- R-1: a weir, slabs protecting the slopes upstream or downstream,

- R-2: weir backwater,

- R-3: stony bottom downstream from a weir,

- R-4: stony bottom upstream from a weir,

- R-5: the bridge piers,

- R-6: river bar and the river section upstream and downstream.

\section{RESULTS}

\section{Invertebrates}

Eighty-one invertebrate taxa (species or higher taxa in the case when the species determination was impossible) were identified -68 on the reaches of mixed (sandy and muddy) bottoms, 57 on the reaches of muddy bottoms and 43 on the reaches of sandy ones. Just 4 taxa were found only in the microhabitats connected with regulated reaches (type $\mathrm{R})$.

The M-7 microhabitat ("deep pool on the inner side of a river bend") was most abundant with invertebrates (53 taxa). On the other hand the "poorest" ones were: M-8 (11 taxa), R-5 (8 taxa) and R-6 (10 taxa). In other microhabitats 29-41 taxa were collected (statistical differences not significant).

Sponges (Ephydatia fluviatilis and Spongilla fragilis), were found only in M-9, R-1 and R-4 microhabitats. Its worth mentioning that on Wkra River they were noticed only (sic!) in the microhabitats connected with the weirs. The only member of hydrozoans group (Hydra attenuata) inhabited R2 and R-4 ones (also only "artificial" microhabitats). The largest number of planarians (5 species) was found in M-7 microhabitat, lack of those invertebrates was typical for R-3 and R-5. Aquatic earthworms - Oligochaeta - (maximal species number in microhabitat -3 ) were absent in M-8, R-2, R-3 and R-5. The highest number of leeches (5 species) were collected in M-5 microhabitat, 4 species in M-7, 3 species - in M-1, M-3, M-9 and R-1. The arthropods were present in all microhabitats -4 taxa in M-10 and R-6, 3 taxa - in M-1, M-3, M-9 and R-1.

Stonefly larvae (3 species maximally) were found only in M-1, M-7 and R-1 microhabitats, mayflies (2 species maximally) - in M-1, M-2, M-7 and M-9; dragonflies (4 species maximally) - in M-5, M-6 and M-7. The highest 
number of caddisfly species (4) was identified in M-7 microhabitat, 3 species - in M-3. The members of that group were absent in M-9, M-10 and all R type microhabitats. The maximal number of water bug species (4) was typical for M-1, M-2 and M-9 microhabitats, the members of that group were absent in M-10 and R-5. The same results were obtained for beetles. Diptera (midges, mosquitoes, gnats and flies) were most abundant in the M-7 microhabitat (6 species in total; 4 species in M-1, M-2 and M-9). The molluscs were not found only in the R-6 microhabitat, the highest number of taxa (4) was collected in M-3 and M-5 ones. The snails were present in all microhabitats (minimally 2 taxa, maximally 6 in M-7 and M-9).

\section{Fish}

Seventeen fish species, with no rarities, were identified in Wkra and Jeziorka repeatable microhabitats. Just like in the case of invertebrates, M-7 was the most abundant one - only one species (tench Tinca tinca) have not occurred. All other microhabitats characterised themselves by the presence of 4-9 species. It is worth noticing that three of the $\mathrm{R}$ type microhabitats shown themselves preferable for 8-9 species, including burbot Lota lota, ide Leuciscus idus and brown trout Salmo trutta morpha fario. The results of fish collecting in all microhabitats are presented in Table 1, below.

\section{DISCUSSION}

The surveys, carried out on the reaches of various rivers, allowed rich comparative material to be obtained, helpful for the studies of lowland river biodiversity and the activities connected with watercourse conservation or renaturation. It is known that various taxa of different ranges are of specific importance for communities and eco-system functioning and - in consequence - for biological system stability not only in the river itself, but also in the valley as a whole (Cummings et al. 1966). The experts need to know as much as possible about the environmental necessities of various species and ecological groups (such as shredders) and the collected data seems to be helpful.

It is worth stressing that all invertebrate groups were noticed in more of the selected microhabitats. Without doubt the peculiar importance for invertebrate diversity in the riverbed should be put down to the presence of deep pools on the inner side of the bends, where most planarians, leeches, bivalves and snails were found. In the case of fish the "advantage" of that microhabitat is even more overwhelming. But even the poorest microhabitat (the bridge piers) proved to be the "record holder" in the case of arthropods. It is also worth mentioning that the artificial microhabitats, connected with the hydrotechnical structures, were inhabited by sponges and hydrozoan Hydra attenuata (not collected in any microhabitat on close-to-nature reaches!). The similar situation was noticed in the case of fish. The well-known fact, that in many rivers the occurrence of some fish species is connected with artificial hydrological elements (for example pike and pikeperch seem to prefer the crossbars - Berkman et al. 1986), is widely discussed. The author does 


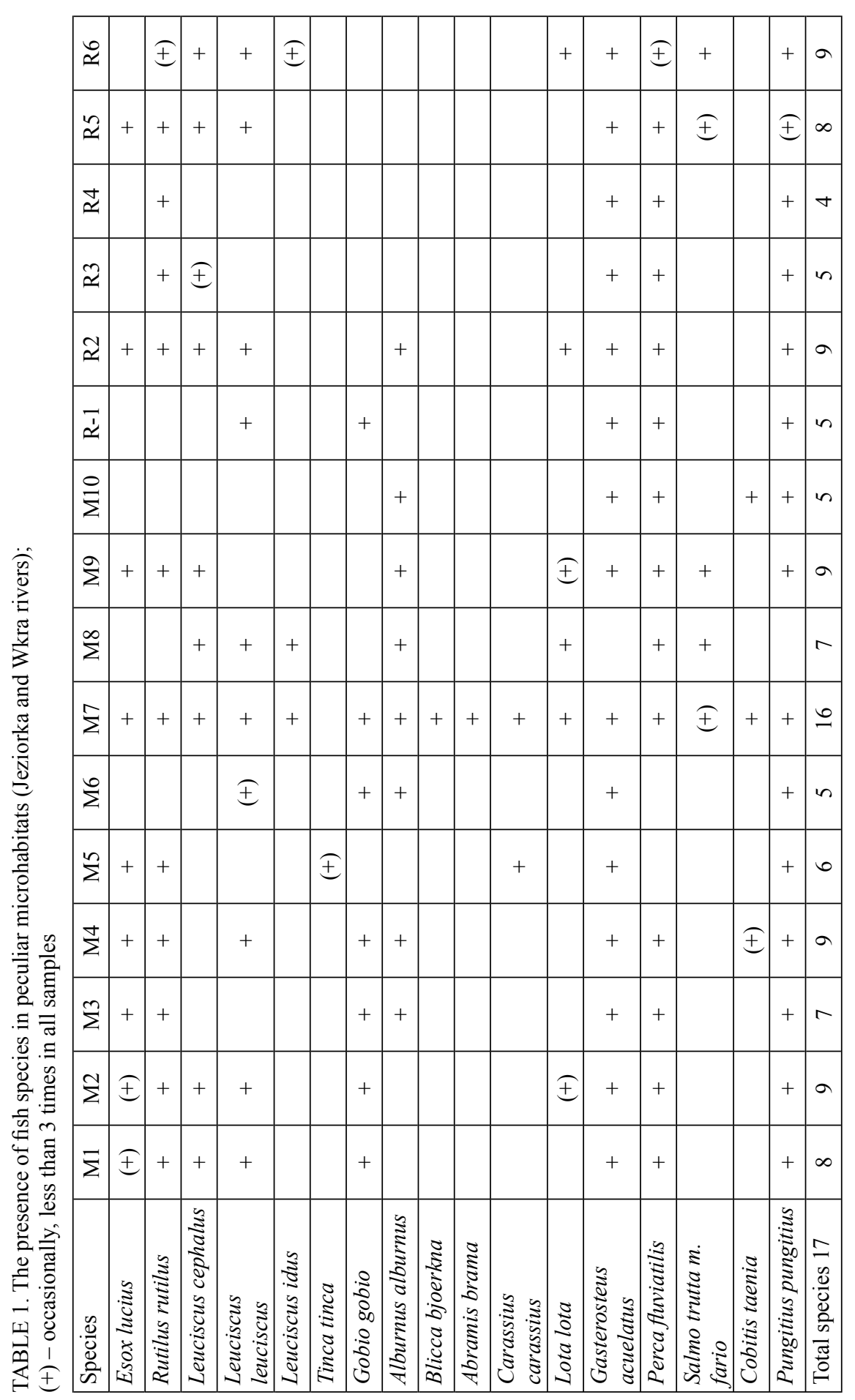


not wish to convince anybody of the necessity of river regulation, but some positive outcomes of such activities may be noticed - when one speaks about biodiversity (and biological attractiveness), not naturalness. There are quite different terms and everybody should consider that fact.

The results confirmed the fact that riverbed differentiation is the key for maintaining watercourse biodiversity. The material for the following analyses was gained, but more detailed surveys on various invertebrate and fish taxa environmental preferences seems to be necessary.

\section{CONCLUSIONS}

1. The different microhabitats may be singled out in small and mediumsized lowland riverbeds.

2. All microhabitat types (even those commonly considered as invaluable) are characterised by peculiar invertebrate and fish fauna.

3. The most preferred (abundant with taxa) microhabitat is the deep pool on the inner side of the bend.

4. The microhabitats connected with hydrological structures may be used by environmentally valuable invertebrate and fish species (sponges, brown trout, burbot).

\section{REFERENCES}

BEISEL J.N., USSEGLIO-POLATERA P., MORETEAU J.C. 2000: The spatial heterogeneity of a river bottom: a key factor determining macroinvertebrate communities. Hydrobiologia 422/423, 163-171, Kluvert Academic Publishers, Netherlands.
BERKMAN H., RABENI C., BOYLE T. 1986: Biomonitors of stream quality in agricultural areas: fish vs. invertebrates. In: Environmental Management 10/3, 413-420.

CUMMINGS K., TRYON C., HARTMAN T. (eds) 1966: Organism-substrate relationships in streams. Spec. Publ. 4 Pymatuning Lab. Ecol. Univ. Pittsburgh, Pittsburgh.

LAMPERT W., SOMMER U. 1993: Inland Water Ecology (in German) Georg Thieme Verlag, Stuttgart, 400 p.

RABENI C., MINSHAL G. 1977: Factors affecting microdistribution of the stream benthic insects. Oikos 29, p. 33-43.

TOLKAMP H.H. 1980: Organism-substrate relationships in lowland streams. Centre for Agricultural Publishing and Documentation, Wageningen.

Streszczenie. Preferencje siedliskowe bezkręgowców i ryb jako kluczowy czynnik różnorodności przyrodniczej koryt niewielkich rzek nizinnych. Na czterech niewielkich rzekach nizinnych przeprowadzono badania fauny bezkręgowej i ryb, występujących w powtarzalnych, charakterystycznych mikrosiedlisk. Podjęto próbę ustalenia znaczenia każdego z takich mikrosiedlisk dla obrazu fauny w cieku oraz obecności określonych taksonów. Zdecydowanie najbogatszym w gatunki bezkręgowców i ryb okazało się mikrosiedlisko zbliżone do natury, opisane jako ,głębokie zakole na łuku wewnętrznym", ale niektóre taksony preferowały nawet habitaty typowo sztuczne, związane z budowlami hydrotechnicznymi, zazwyczaj niekojarzone ze wzrostem bogactwa gatunkowego. Nawet $\mathrm{w}$ najmniej różnorodnym siedlisku opisanym jako „kamieniste bystrze powyżej jazu” stwierdzono 4 możliwe do oznaczenia taksony. Dokładna analiza wyników pozwala dostrzec skalę problemu, jakim jest związek zabudowy rzek $\mathrm{z}$ ich różnorodnością przyrodniczą. Niezbędne wydają się dalsze szczegółowe badania nad wzajemnymi relacjami pomiędzy mikrosiedliskami rzecznymi a preferującą je fauną.

\section{MS. received November 2008}

\section{Author's address:}

Nowoursynowska 159 02-767 Warsaw, e-mail: oglecki@poczta.onet.pl 